\title{
Des(p)ejo das palavras: relendo os primeiros diários de Carolina Maria de Jesus
}

\author{
Rafael Guimarães Tavares da Silva' ${ }^{1}$ (i) 0000-0002-8985-8315 \\ 'Universidade Federal de Minas Gerais, Faculdade de Letras, Pós-Graduação em \\ Estudos Literários, Belo Horizonte, MG, Brasil. 31270-901
}

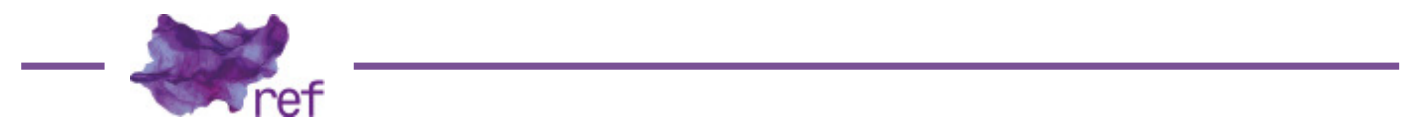

Resumo: A obra de estreia de Carolina Maria de Jesus, Quarto de despejo, foi sucesso de público, embora suas obras seguintes tenham sido envoltas por um silêncio profundo no Brasil. Buscando situar esse silêncio na problemática que diz respeito à figura de uma escritora "pobre, negra e mulher", pretendo reler seus primeiros diários e sugerir certos aspectos de seu fecundo trabalho com a linguagem, demonstrando a existência de um processo poderoso e emancipatório de subjetivação, ainda que não isento de ambiguidades.

Palavras-chave: teoria literária; escrita de si; desconstrução; literatura brasileira; Carolina Maria de Jesus.

Ejoyctment of Words: Re-Reading the First Diaries of Carolina Maria de Jesus

Abstract: Carolina Maria de Jesus' debut work, Quarto de despejo [Child of the Dark], was a bestseller, although her next works were shrouded in a deep silence in Brazil. Seeking to situate this silence in the question related to the figure of a writer who is "poor, black and woman", I intend to re-read her first diaries and suggest certain aspects of her fertile work with language, demonstrating a powerful and emancipatory process of subjectivation, albeit not free of ambiguities.

Keywords: Literary theory; Self writing; Deconstruction; Brazilian literature; Carolina Maria de Jesus.

\section{Introdução}

Antes de começar, é preciso - aqui - pedir perdão. Pedir perdão por falar onde seria necessário antes de tudo calar. Calar... Mas dar a ouvir. Dar a ouvir essa voz que buscou desesperadamente ressoar e que foi tantas vezes silenciada. E que foi silenciada de forma ainda mais violenta depois de um momento de aparente ressonância nacional - apoiada por um frisson midiático - apenas para se ver condenada a uma espécie de limbo literário, sem direito a qualquer recurso. Ainda assim, os ecos dessa voz continuam a vibrar, saindo dos fundos de um quarto de despejo.

Aqui seria preciso retomar a questão que se coloca Gayatri Spivak, em seu incontornável texto, Pode o subalterno falar?, e retomar ainda sua contundente resposta: "O subalterno não pode falar. Não há valor algum atribuído à 'mulher' como um item respeitoso nas listas de prioridades globais" (SPIVAK, 2014, p. 165). E, pensando no caso específico de Carolina Maria de Jesus, "pobre, negra e mulher", é preciso compreendê-la como alguém que está envolvida de três maneiras nessa impossibilidade de falar (SPIVAK, 2014, p. 110). ${ }^{1}$

Ao falar aqui, estou ciente da ambiguidade de meu gesto: há o risco de que eu abafe a voz de Carolina e venha a calá-la justamente por meio daquilo que pareceria um gesto de desvelo. ${ }^{2}$ Assumo o risco, contudo, buscando fazer com que meu desvelo - naquilo que torne possível uma leitura atenta - apenas a desvele. Falo, portanto, e assim o faço com o intuito de abrir um espaço

\footnotetext{
1 Para detalhes sobre a lógica interseccional segundo a qual diferentes formas de opressão combinam-se e potencializam-se - tal como demonstrado a partir da história social estadunidense, cf. Angela DAVIS, 2016.

${ }^{2}$ A lógica ambígua desse gesto foi denunciada com argúcia pela própria Spivak (2014, p. 118-165).
} 
para que esses ecos se amplifiquem e alcancem novos horizontes: horizontes para além daqueles silêncios aos quais sua voz tem sido condenada. Pois a decisão de me calar aqui agora, deixando passar essa oportunidade para uma interlocução entre ecos de diferentes tempos e espaços, seria talvez me associar à lógica que trabalha para silenciar essa voz tão forte e contundente quando devidamente escutada.

Carolina Maria de Jesus nunca pôde falar de fato: desde as recusas iniciais a suas obras, passando pela primeira publicação de seus diários - com todos os cortes que seu editor abriu em seu corpus, para evitar que "a repetição da rotina favelada" fosse "exaustiva" (Audálio DANTAS, 1993, p. 3) -, até o silêncio a que seus últimos escritos foram submetidos no Brasil, a voz de Carolina nunca ressoou livre dos preconceitos que pesavam sobre ela: "negra, pobre e mulher". Repetidamente, a autora via suas palavras serem recusadas a toda e qualquer possibilidade de escuta:

16 de junho de 1958. [...] ... Eu escrevia peças e apresentava aos diretores de circos. Eles respondia-me:

- É pena você ser preta. (JESUS, 1993b, p. 58)

5 de novembro de 1958. [...] - Pois é, Toninho, os editores do Brasil não imprime o que escrevo porque sou pobre e não tenho dinheiro para pagar. Por isso eu vou enviar o meu livro para os Estados Unidos. Ele deu-me varios endereços de editoras que eu devia procurar. (JESUS, 1993b, p. 117)

16 de janeiro de 1959. ... Fui no Correio retirar os cadernos que retornaram dos Estados Unidos. (...) Cheguei na favela. Triste como se tivessem mutilado os meus membros. O The Reader Digest devolvia os originais. A pior bofetada para quem escreve é a devolução de sua obra. (JESUS, 1993b, p. 135)

Se a devolução de sua obra é a pior bofetada para quem escreve, a publicação da obra de uma "negra pobre" só será tornada possível por meio de uma efetiva mutilação de seu corpus. O processo de editoração dos primeiros diários de Carolina, levado a cabo por Audálio Dantas e responsável por deixar frequentes cicatrizes na superfície desse corpo textual - sob a forma dos estigmas das reticências (...) -, foi estudado por Elzira Divina Perpétua (2014, p. 137-67). A estudiosa, analisando os manuscritos originais e cotejando-os com o material que veio a ser efetivamente publicado, tece considerações sobre os acréscimos, as substituições e as supressões impostas ao texto por seu editor e reflete sobre as motivações por trás disso. Conforme a estudiosa:

As modificações realizadas na transposição dos manuscritos para o livro publicado mostram que o projeto de Quarto de despejo realizou-se como um ato intencionalmente predeterminado de conferir à publicação um valor de representação coletiva da miséria e do abandono do favelado. Para cumprir esse objetivo, foi necessário que o editor adaptasse a narradora a um modelo de sujeito que convergisse para uma personagem que, além de íntegra, forte, resignada e atenta aos problemas da comunidade, fosse também submissa, passiva, sem capacidade de julgamento, sem liberdade interior - enfim, produto e não produtora de um destino. Esse perfil de Carolina é que teria guiado o editor às inumeráveis modificações do original, das quais apresentamos uma amostra. (PERPÉTUA, 2014, p. 167)

A amostra das modificações apresentadas pela estudiosa sugere que o editor suprimiu passagens de efusão lírica, de manifestação do bem-estar em plena miséria, de conhecimento do cânone filosófico (como sugerem menções a Sócrates e ao valor da palavra como forma de combate à violência), entre outras, para conformar a imagem de uma autora da favela - tal como delineada a partir de sua obra autobiográfica - ao horizonte de expectativa do público a esse respeito. Trata-se, portanto, de restringir a expressividade de um sujeito subalterno aos limites estritos de sua posição subalterna. ${ }^{3}$

Aqui seria importante ressalvar que essas observações não são uma acusação ao trabalho específico de Audálio Dantas, mas à lógica do próprio sistema (literário e social). Levando em conta os depoimentos de Carolina a esse respeito, o trabalho de seu editor parece ter visado questões práticas e, por mais que suas opções sejam altamente questionáveis, obteve sucesso na campanha publicitária responsável por fazer com que sua voz tivesse alguma ressonância num primeiro momento (PERPÉTUA, 2014, p. 60). Alguns estudos debruçam-se sobre essa primeira recepção, cotejando-a com o que se sucedeu com suas obras seguintes no Brasil e no mundo, como os de Marisa Lajolo (201 1, p. 439-444), Germana Sousa (2012, p. 55-78) e Divina Perpétua (2014, p. 39-135). Tudo indica que,

[s]em suporte prolongado na mídia e sem nenhum apoio nas malhas centrais do sistema literário, os livros de Carolina Maria de Jesus, com exceção de Quarto de despejo, foram fracasso de

\footnotetext{
${ }^{3}$ Após o importante estudo inaugural de Perpétua (2014), outros trabalhos têm se debruçado sobre as facetas pouco conhecidas - posto que deliberadamente ignoradas pelas editoras e de difícil acesso ao público leitor - da vasta obra inédita de Carolina. A título de exemplo, cf. Raffaella Andréa FERNANDEZ, 2015.
} 
crítica e de público, embora a escritora continuasse despertando grande interesse no exterior. (LAJOLO, 2011, p. 441-442)

Em que pese a quantidade de traduções e publicações em torno de sua obra no estrangeiro, além de efêmeras retomadas também nos estudos acadêmicos no Brasil, a recepção de Carolina foi pautada mais pelo silêncio ou pela tentativa de deslegitimação de seu valor literário do que por uma escuta de fato (SOUSA, 2012, p. 166). Mesmo em muitas das vezes em que foi lida com um olhar a princípio favorável, a recepção que certos críticos ofereceram à sua obra se deu na chave de seu valor testemunhal - chamando atenção à dimensão documental de seu texto -, em detrimento de seu valor propriamente estético, como se houvesse uma incompatibilidade entre esses aspectos (SOUSA, 2012, p. 75). Nesse sentido, críticos como Marilene Felinto e Wilson Martins (acusando a escassez de valor literário nas obras de Carolina), assim como Roberto Da Matta (respondendo a essas acusações com uma demonstração da importância social de um testemunho literário como o de Carolina), divergem antes de tudo na concepção de literariedade por trás de suas críticas (SOUSA, 2012, p. 75-78). ${ }^{4}$ Aqui é importante salientar que não há crítica literária sem um critério - ou seja, sem um valor a partir do qual se paute seu juízo - e não há critério que não pressuponha uma concepção teórica acerca do objeto literário. Em outras palavras, não há crítica sem teoria.

As diferentes definições de 'literatura' são responsáveis por decidir se certas manifestações humanas podem ser incluídas ou não no rol de produtos culturais prestigiosos, na medida em que os critérios empregados para avaliá-las são capazes de conceder-lhes o valor social de que virão a desfrutar. Tal como afirmado por Regina Dalcastagnè (2007, p. 21), "a valoração sistematicamente positiva de uma forma de expressão, em detrimento de outras, faz da manifestação literária o privilégio de um grupo social." Que esse grupo seja composto majoritariamente por homens, brancos, heterossexuais e membros das classes mais altas da sociedade não é sem relação com o fato de que justamente tais indivíduos tenham tradicionalmente gozado (e ainda gozem) de um prestígio social responsável não apenas por lhes assegurar as melhores condições de vida e educação, mas também os meios sociais mais eficazes para ingressarem no cânone literário. A mesma lógica, mutatis mutandis, explica as razões por trás de certos 'esquecimentos' que sofreram (e ainda sofrem) as obras literárias de mulheres e negros - ou, ainda mais, de negras - por parte dos responsáveis pela definição do cânone. ${ }^{5}$

Para simplificar um pouco essa discussão, cito aqui os cinco elementos básicos sugeridos por Antoine Compagnon (2010, p. 25) como constitutivos de toda teoria literária responsável por embasar um juízo crítico, a fim de retomá-los e desdobrá-los numa possível leitura do Quarto de despejo: a autora, o livro, a recepção, a língua e o referente. Acrescentaria ainda a dimensão editorial do livro. Acredito que uma crítica literária efetiva deva contemplar - em seu jogo infinito de desdobramentos - pelo menos esses seis aspectos da obra literária a fim de propor uma leitura justa do texto que tem diante de si. É inevitável que o intérprete valorize algumas dimensões mais do que outras - segundo suas próprias opções estéticas, éticas e epistemológicas-, mas é sempre interessante explicitar suas razões para tal, a fim de evitar que certos preconceitos de classe, gênero e raça se infiltrem quase imperceptivelmente em juízos críticos que se pretendam 'universais', 'objetivos', 'neutros', 'racionais' e 'imparciais'.

Sobre a autora, minhas breves considerações acerca de sua condição de subalterna indicam a importância desse elemento para aquilo que pretendo dar a ver ao longo deste texto. Levando em conta as discussões sobre o lugar de fala, a autobiografia e a literatura de testemunho, acredito que o elemento biográfico seja crucial para a compreensão do discurso de Carolina Maria de Jesus. ${ }^{7}$ Ele é tematizado em inúmeras passagens de sua obra e articula outros elementos literários, como a edição e a recepção que lhe foram dadas (qual visto acima), além dos referentes do mundo abordados por ela e seu trabalho com a linguagem.

\footnotetext{
${ }^{4}$ Como observado no parecer ao presente artigo, a discussão segue viva, conforme se depreende do debate ocorrido durante e após o evento "Mulheres na Literatura", promovido pela Academia Carioca de Letras em 17 de abril de 2017. Em sua apresentação, Ivan Cavalcanti Proença afirmou que não considera literária a obra de Carolina, mas sim "o relato natural e espontâneo de uma pessoa que não tinha condições de existir por completo". Na sequência, a poeta Elisa Lucinda fez uma apaixonada defesa do valor literário da autora de Quarto de despejo, ressaltando a importância de se conhecer toda a sua obra. O debate avivou-se ainda mais com publicações nas semanas seguintes ao evento. Para mais detalhes dessa discussão recente - cujas indicações bibliográficas me foram generosamente oferecidas por quem escreveu o parecer do presente artigo -, cf. Maria FORTUNA, 2017; Cleo GUIMARÃES; FORTUNA, 2017; Elisa LUCINDA, 2017; Miriane PEREGRINO, 2017.

${ }^{5} U$ ma contundente problematização dessas questões é desenvolvida pelo texto de Zahidé Lupinacci Muzart (1995). ' Para uma crítica contumaz à pretensão de 'universalidade' por trás dos juízos pautados por critérios empregados pela classe tradicionalmente hegemônica e composta por homens brancos, heterossexuais e das classes mais altas, cf. Djamila RIBEIRO, 2017, p. 83-90.

7 Entendo o conceito de "Iugar de fala" a partir do que foi desenvolvido por Ribeiro $(2017$, p. 86), ao sugerir sua relação com uma "localização social" a partir da qual se torna possível "debater e refletir criticamente sobre os mais variados temas presentes na sociedade". Para uma interessante reflexão sobre "lugar da fala" e "lugar da escuta", a partir da obra de Carolina, cf. DALCASTAGNĖ, 2007, p. 22-25.
} 
Acerca dos referentes a partir dos quais a autora parte para tecer sua narrativa, é possível resumi-los na expressão lapidar usada por ela durante uma entrevista: "Escrevo a miséria e a vida infausta dos favelados" (JESUS, 1993a, p. 171). Os referentes de sua obra, relacionados à vida da autora e ao mundo em que viveu, são explicitados de forma ainda mais significativa numa expressão empregada em seu diário, quando ela afirma o seguinte (em 28 de maio de 1959): "A vida é igual um livro. Só depois de ter lido é que sabemos o que encerra. E nós quando estamos no fim da vida é que sabemos como a nossa vida decorreu. A minha, até aqui, tem sido preta. Preta é a minha pele. Preto é o lugar onde eu moro" (JESUS, 1993b, p. 147). Há, portanto, uma aspiração deliberada de fazer coincidir a vida da autora, seu mundo e seu livro.

\section{Parataxe da miséria}

Um desdobramento de sua aspiração de promover uma coincidência entre a vida da autora, seu mundo e seu livro tem lugar numa construção típica de Carolina. Por falta de expressão melhor, tendo a compreendê-la como uma espécie de "parataxe da miséria". Desenvolvo aqui um conceito a partir de Theodor Adorno, proposto em sua leitura da poesia de Hölderlin, ao destacar a importância da materialidade da linguagem desse poeta para questionar tanto os pressupostos de uma unidade entre forma e sentido quanto a existência de uma hierarquia entre sujeito e objeto. A aposição de diferentes elementos no interior de uma estrutura paratática - isto é, no interior de uma construção coordenada (e não subordinada) -leva a um questionamento formal das hierarquias tradicionais do pensamento hegemônico, na medida em que recusa a categorização desses elementos no interior de uma ordem subordinativa (isto é, impositiva). ${ }^{8}$ Na formulação de Adorno:

Seja segundo a intenção de Hölderlin, seja segundo as próprias coisas, o sacrifício do período foi levado ao grau mais extremo. Poeticamente, isso representa o sacrifício do próprio sujeito legislador. Com isso, em Hölderlin, o movimento poético transtorna pela primeira vez a categoria do sentido. Pois o sentido constitui-se através da expressão linguística da unidade sintética. (ADORNO, 1997, p. 477, trad. minha)

Em Hölderlin, esse questionamento da prioridade do sentido se dá por meio de um enlouquecimento da sintaxe, abrindo assim a possibilidade de que a própria linguagem expresse seu sujeito. Em Carolina Maria de Jesus, a miséria experimentada pela autora não é apenas tematizada pela linguagem empregada em sua narrativa, mas, penetrando a própria linguagem, abole as categorias tradicionais do pensamento e leva a uma aposição de elementos disparatados dessa realidade miserável no interior de uma estrutura paratática. Que se considere a seguinte passagem:

31 de dezembro de 1958. [...] A favela está agitada. Os favelados demonstram jubilo porque findaram um ano de vida.

Hoje uma nortista foi para o hospital ter filhos e a criança nasceu morta. Ela está tomando soro. A sua mãe está chorando, porque ela é filha única.

Tem baile na casa do Vitor. (JESUS, 1993b, p. 131)

A parataxe da miséria diz respeito não apenas à abolição das hierarquias entre os elementos responsáveis por subordinar certos argumentos norteadores de uma proposição, mas também à aposição sem ordem aparente de elementos disparatados da miséria imperante - formando um catálogo de desgraças e pequenas alegrias -, além de um emprego livre dos tempos verbais (presente, passado e futuro). É de se notar que - mesmo se a impressão de parataxe da miséria tenha sido, em certa medida, criada pelas próprias intervenções editoriais de Audálio Dantas, tal como sugere Perpétua $(2014$, p. 158) - o efeito de uma aposição de elementos disparatados da miséria encontra-se na forma em que o próprio texto veio a ser publicado e ajuda a explicitar o que está em jogo na interseção entre a biografia da autora, o livro, o referente e o editor.

Em todo caso, a própria estrutura do gênero literário empregado na obra acentua esse aspecto aqui chamado de parataxe da miséria. Conforme Marisa Lajolo:

A estrutura fragmentada do diário - particularidade do gênero - parece reforçar a redundância das cifras de uma aritmética simples de adição e subtração, que configura o relato das carências cotidianas, miúdas e graúdas, dentre as quais a fome e a comida adquirem perfil de experiência estética. Na sucessão de registros, as cifras mencionadas vão tendo alterado seu sentido de mera denotação contábil, adquirindo valor conotativo que expressa, em sua aparente frieza e objetividade, a subjetividade das vidas que por elas se medem. (LAJOLO, 2011, p. 443)

A contabilidade da vida miserável de Carolina e dos demais moradores da favela do Canindé sugere a falta de valor dos diversos elementos que a compõem: intercambiáveis pelos

\footnotetext{
${ }^{8}$ Nesse arranjo sintático, portanto, prevalecem as orações coordenadas - não as subordinadas - e, na medida em que cada uma das partes da sentença é justaposta às demais, não há subordinação da parte perante o todo. Para considerações sobre as implicações desse aspecto formal sobre a interpretação de uma obra literária como a de Hölderin (ou a de Carolina Maria de Jesus), cf. Sara SILVEIRA, 2012, p. 90-92.
} 
poucos tostões que são obtidos por uma labuta diária para catar papel e ferro, comida, roupa, eletricidade e outras coisas parecem indicar a mais indiferente fungibilidade dessas existências numa espécie de morte em vida. Conforme as palavras da própria autora, numa anotação de 7 de junho de 1958:

Eu e a Vera fomos catar papel. Passei no Frigorifico para pegar linguiça. Contei 9 mulheres na fila. Eu tenho a mania de observar tudo, contar tudo, marcar os fatos.

Encontrei muito papel nas ruas. Ganhei 20 cruzeiros. Fui no bar tomar uma media. Uma para mim e outra para a Vera. Gastei 11 cruzeiros. Fiquei catando papel até as 11 e meia. Ganhei 50 cruzeiros. (JESUS, 1993b, p. 48)

Como se vê, a parataxe da miséria tem entre seus elementos essa contabilidade miúda que também abole as hierarquias entre as diferentes prioridades para a manutenção da vida: alimentação, vestuário, moradia e transporte, esses diferentes aspectos da subsistência desfilam páginas a fio por detrás do cálculo de quantos cruzeiros são necessários para que a vida, mesmo nas mais precárias condições, ainda se mantenha. E essa precariedade está presente também na permanência de restos que se recusam a desaparecer: migalhas de comida, trapos de roupa, pedaços de casa, todas as coisas adquirem uma resistência material própria e - mesmo quando apodrecem passam a fazer parte de uma realidade para além da qual foram inicialmente projetadas.

Esse mesmo conteúdo de uma parataxe da miséria também é responsável por dar forma a uma dicção muito própria, na qual certos arcaísmos e preciosismos de linguagem - resgatados de livros velhos e publicações antigas - ganham certa permanência e passam a conviver com um registro cotidiano da linguagem oral e informal. Tal arranjo é responsável por colocar esses registros linguísticos em pé de igualdade no interior de seu discurso, abolindo as distinções estritas entre uma linguagem formal elevada e sua manifestação informal, rebaixada. Retomando aqui, mais uma vez, as palavras de Lajolo:

Os registros são vazados numa linguagem cuja peculiaridade vai além das cifras: infrações da gramática e da ortografia convivem com um léxico alambicado, que se marca pelo preciosismo fora de moda, na moldura de uma narração desataviada, de frases curtas e imagens que dão concretude à visão de mundo que exprimem. Encontra-se assim em Quarto de despejo um texto mestiço, onde convive o rebuscamento do palavreado às vezes raro com infrações comezinhas das normas gramaticais. (LAJOLO, 2011 , p. 443)

O caráter "mestiço" dessa obra é responsável por grande parte de sua estranheza: referências bíblicas e clássicas misturam-se com a narrativa das misérias cotidianas; alusões a figuras públicas da política de então confundem-se na perspectiva da narradora com os atos e fatos da vida na favela. Carolina introduz um estranhamento radical com relação àquilo que habitualmente se julga ser a língua, qual seja, mero portador de sentido, mero instrumento de comunicação. ${ }^{9} \mathrm{~A}$ obra de Carolina significa-se para além de um centro que regule seu sentido, transbordando em direção tanto às ambiguidades da realidade social de que trata, quanto ao hibridismo da linguagem que ela emprega para retratá-la. Retomo aqui as palavras de Julia Kristeva, no que tange a essa dupla injunção entre linguagem e sociedade, pois acredito ser possível aplicá-las ao que acontece no texto de Quarto de despejo:

Transformando a matéria da língua (sua organização lógica e gramatical), para aí transportando a relação das forças sociais da cena histórica (em seus significados regulados pela situação do sujeito do enunciado comunicado), o texto se liga - se lê - duplamente em relação ao real: à língua (alterada e transformada) e à sociedade (com cuja transformação se harmoniza). [...] O texto está pois, duplamente orientado: para o sistema significante no qual se produz (a língua e a linguagem de uma época e de uma sociedade precisa) e para o processo social do qual participa enquanto discurso. (KRISTEVA, 1974, p. 12)

Exemplos dessa dupla injunção no interior do jogo intertextual trabalhado por Carolina abundam em sua obra, mas acredito ser o suficiente citar aqui apenas alguns exemplos:

5 de novembro de 1958. [...] Quando Jesus disse para as mulheres de Jerusalem: - "Não chores por mim. Chorae por vós" - suas palavras profetisava o governo do senhor Juscelino. Penado de agruras para o povo brasileiro. Penado que o pobre há de comer o que encontrar no lixo ou então dormir com fome. (JESUS, 1993b, p. 117)

25 de dezembro de 1958. [...] ...Na minha opinião os atacadistas de São Paulo estão se divertindo com o povo igual os Cesar quando torturava os cristãos. Só que o Cesar da atualidade supera - Cesar do passado. Os outros era perseguido pela fé. E nós, pela fome!

\footnotetext{
${ }^{9}$ Ainda que eu não adote a teoria formalista de Julia Kristeva, sua formulação sobre a importância do estranhamento para o desenvolvimento de uma certa concepção de literatura pode ser aqui citada com proveito: "O ato chamado literário, por não admitir a distância ideal em relação àquilo que significa, introduz o estranhamento radical relativamente ao que se julga ser a língua - um portador de sentido. Estranhamente próxima, intimamente estranha à matéria de nossos discursos e de nossos sonhos, a 'literatura' nos parece, hoje, ser o ato mesmo que apreende como a língua funciona e indica o que ela amanhã, tem o poder de transformar" (KRISTEVA, 1974, p. 9-10).
} 
Naquela epoca, os que não queriam morrer deixavam de amar a Cristo.

Mas nós não podemos deixar de comer. (JESUS, 1993b, p. 129)

O texto de Carolina torna-se um terreno em que vários aspectos de sua linguagem e da sociedade, vistos de sua perspectiva, convivem da forma mais disparatada - ou seja, segundo uma parataxe da miséria -, vendo-se atravessado por diferentes vozes e enunciados de diferentes tradições (bíblica, clássica, popular e midiática). Esses elementos são organizados segundo a perspectiva de uma narradora que coincide com a da própria autora, embora a miséria de sua existência - tanto da narradora quanto da autora - impeçam uma hierarquização estanque desses elementos: seu jogo disparatado evidencia com isso os dilemas que a vida miserável escancara.

\section{Lógica do despejo}

Outro desdobramento da parataxe da miséria revela-se no livro de Carolina a partir daquilo que poderia ser chamado - num primeiro momento - de lógica do despejo. Trata-se da compreensão e da exposição de um mecanismo cujos reflexos no livro são bastante claros, tendo implicações para muito do que acontece e do que é narrado, sendo interessante ressaltar que os desdobramentos dessa lógica são tanto sociais, quanto linguísticos, psicanalíticos e jurídicos (embora eu vá me concentrar aqui em sua dimensão social). Um esboço esquemático dessa lógica do despejo seria o seguinte: as violências são sempre despejadas contra grupos hierarquicamente inferiores (ou, no mínimo, de mesmo status social), implicando um complexo jogo de transferência da violência entre os diferentes grupos da sociedade.

No alto desse arranjo piramidal, o grupo dos políticos é aquele que trama o maior número de violências, mentiras e enganos, sem se preocupar diretamente com o resultado de suas ações, pois se encontra muito distante do resto da população para sofrer as consequências de seus atos: tal é o caso do deputado dr. Contrini, do deputado Francisco Franco e da deputada Conceição da Costa Neves (JESUS, 1993b, p. 94; p. 96; p. 100). Ainda que Carolina afirme que o povo tem consciência do engodo por trás das eleições e de todo o esquema político, ${ }^{10}$ a narradora constata sua impotência para mudar de fato a situação:

31 de outubro de 1958. [...] ... O Povo está dizendo que o Dr. Adhemar elevou as passagens para vingar do povo porque lhe preteriram nas urnas.

Quando cheguei em casa os filhos já estavam em casa. Esquentei a comida. Era pouca. E eles ficaram com fome.

... Nos bondes que circulam vai um policial. E nos ônibus tambem. O povo não sabe revoltar-se. Deviam ir no Palacio do lbirapuera e na Assembléia e dar uma surra nestes politicos alinhavados que não sabem administrar o país. (JESUS, 1993b, p. 114)

O grupo seguinte, restrito a homens brancos, inclui policiais, religiosos, intelectuais, o pai da Vera, além do próprio Audálio Dantas, repórter responsável pela publicação e edição dos primeiros livros de Carolina. Embora esse grupo ainda faça parte dos privilegiados que cometem suas violências sem ter que temer quaisquer consequências pesadas, já existe alguma proximidade entre eles e a sociedade retratada em Quarto de despejo. Essa proximidade é tanto para bem quanto para mal, pois esse grupo não se esconde por trás da mesma barreira que o grupo dos políticos.

Antes de sugerir o retrato que a narradora faz de cada um desses subgrupos, convém notar a consciência aguda que ela demonstra sobre o processo histórico de predominância masculina:

7 de junho de 1958. [...] ... Quando eu era menina o meu sonho era ser homem para defender o Brasil porque eu lia a Historia do Brasil e ficava sabendo que existia guerra. Só lia os nomes masculinos como defensor da patria. Então eu dizia para a minha mãe:

- Porque a senhora não faz eu virar homem? (JESUS, 1993b, p. 48)

15 de agosto de 1958. [...] ... O povo estava esperando o Anselmo aparecer para lhe expancar. Reuniram homens e mulheres para o bate-fundo.

... Ouvi dizer que o Anselmo pulou a cerca e saiu pelo fundo. Eu disse que eu queria ser homem, porque assim eu podia quebrar e bater. Então um homem respondeu:

- Eu queria ser mulher, mas só de dia.

E todos sorriram. (JESUS, 1993b, p. 99)

Carolina aspira à condição de sujeito histórico ativo - papel que estava (e ainda está em larga medida) reservado como privilégio masculino. Isso não a impede, contudo, de compartilhar de uma série de preconceitos misóginos que eram (e ainda são) socialmente vigentes: as mulheres

\footnotetext{
${ }^{10}$ É de se notar aqui o emprego de outra imagem clássica para a construção de seu argumento: "... Nas ruas e casas comerciais já se vê as faixas indicando os nomes dos futuros deputados. Alguns nomes já são conhecidos. São reincidentes que já foram preteridos nas urnas. Mas o povo não está interessado nas eleições, que é o cavalo de Troia que aparece de quatro em quatro anos" (JESUS, 1993b, p. 39).
} 
como tagarelas, traiçoeiras e provocantes. ${ }^{11}$ Esse comportamento faz parte também da lógica do despejo, como se há de ver na sequência do argumento.

Por ora, basta retomar aqui alguns exemplos da perspectiva de Carolina sobre o domínio exercido pelos subgrupos ou indivíduos pertencentes ao grupo histórico-socialmente privilegiado dos homens brancos. Entre outros trechos (JESUS, 1993b, p. 68), eles incluem policiais:

11 de agosto de 1958.... Eu estava pagando o sapateiro e conversando com um preto que estava lendo um jornal. Ele estava revoltado com um guarda civil que espancou um preto e amarrou numa arvore. O guarda civil é branco. E há certos brancos que transforma preto em bode expiatorio. Quem sabe se guarda civil ignora que já foi extinta a escravidão e ainda estamos no regime da chibata? (JESUS, 1993b, p. 96)

Eles incluem também certos grupos religiosos. Os mais frequentes são os padres e freis católicos, frequentemente acusados de hipocrisia pela narradora do diário (JESUS, 1993b, p. 76; p. 124; p. 126). Há também os crentes, cujo conservadorismo moral é enaltecido numa ocasião por Carolina (1993b, p. 81), embora seja motivo para um trocadilho sexual - entre "crente" e "quente" - em outra (JESUS, 1993b, p. 96). Finalmente, os espíritas aparecem como pessoas sinceramente dispostas a amainar o sofrimento dos pobres, por meio de doações efetivas (JESUS, 1993b, p. 10; p. $89 ;$ p. 128).

Sobre os intelectuais, filmando "As proezas do Promessinha" na favela, muito pouco é afirmado. Eles são representados como gente de boa vida, embora se prestem à admiração e a certo orgulho por parte de Carolina, quando ela afirma:

13 de agosto de 1959. [...] (...) Admirei a polidez dos artistas da Vera Cruz. É uma companhia cinematografica nacional. Merece deferencia especial. Permaneceram o dia todo na favela. A favela superlotou-se. E os visinhos de alvenaria ficaram comentando que os intelectuais dão preferencia aos favelados. (JESUS, 1993b, p. 166)

Ainda no grupo de homens brancos, encontram-se o pai da Vera e o próprio Audálio Dantas. Uma profunda ambiguidade perpassa ambas as relações entre esses homens e Carolina. No que diz respeito ao primeiro, é certo que ele e Carolina têm um envolvimento afetivo, sendo possível que seu envolvimento sexual ainda se mantenha, ${ }^{12}$ embora o descaso com que ele a trata e a exigência de que seu nome não seja revelado no diário constituam motivos para problemas financeiros e incômodos para a escritora. ${ }^{13}$ Audálio Dantas é um caso ainda mais complicado, pois, uma vez que esteve envolvido no processo de edição do texto publicado, sua imagem na obra foi resultado também de suas próprias intervenções textuais, como bem sugere o estudo de Perpétua (2014, p. 201-215). Em todo caso, Carolina afirma o seguinte: "tem hora que eu odeio o reporter Audálio Dantas" (JESUS, 1993b, p. 109). Contudo, pouco depois, também chega a se mostrar agradecida por seus esforços para publicar sua obra (JESUS, 1993b, p. 150).

Dentro do grupo dos brancos, retratados como bem de vida, ainda que tendo algum contato com a realidade da favela, cabe citar agora o grupo das mulheres. Embora não tenham tanta influência quanto os homens brancos, elas parecem usufruir de uma mesma imunidade com relação à miséria da favela e gozam da mesma possibilidade de interferir nela (para bem ou para mal). Dentre aquelas que interferem para bem na vida de Carolina, estão a senhora Alice, a dona Guilhermina, a senhora Julita ou a repórter loira que tenta obter um auxílio para a escritora (JESUS, 1993b, p. 27; p. 89; p. 118; p. 151). Mas há também muitas que se dedicam a perpetrar atos de violência a fim de certificar-se da manutenção de uma exclusão social que implica na permanência de uma lógica do despejo: só isso justifica que algumas deem verdadeiros "presentes envenenados" para os que estão socialmente abaixo delas (JESUS, 1993b, p. 50; p. 90). É o que fica claro quando a narradora afirma:

14 de junho de 1958. [...] Outra mulher reclamava que passou numa casa e pediu uma esmola. A dona da casa mandou esperar (...) A mulher continuou dizendo que a dona da casa surgiu com um embrulho e deu-lhe. Ela não quiz abrir o embrulho perto das colegas, com receio que elas pedissem. Começou pensar. Será um pedaço de queijo? Será carne? Quando ela chegou em casa, a primeira coisa que fez, foi desfazer o embrulho porque a curiosidade é amiga das mulheres. Quando desfez o embrulho viu que eram ratos mortos.

Tem pessoas que zombam dos que pedem. (JESUS, 1993b, p. 55)

\footnotetext{
"A título de exemplo: "1 1 de junho de 1958. ... Já faz seis meses que eu não pago a agua. 25 cruzeiros por mês. E por falar na agua, o que eu não gosto e tenho pavor é de ir buscar agua. Quando as mulheres aglomeram na torneira, enquanto esperam a sua vez para encher a lata vai falando de tudo e de todos" (JESUS, 1993b, p. 51). Para outras passagens: JESUS, 1993b, p. 80; p. 81; p. 83; p. 97; p. 130; p. 157.

${ }^{12}$ Como sugerem as menções ao fato de que o homem daria dinheiro para os filhos de Carolina irem comprar doces, a fim de que os dois ficassem sozinhos em casa (JESUS, 1993b, p. 150; p. 156).

${ }^{13}$ Nas palavras da própria Carolina: "12 de agosto de 1959. [...] O pai da Vera sempre me pede para eu não por o nome dele no jornal. Que ele tem varios empregados e não quer ver o nome propalado. Mas ele não contribui para eu ocultar o seu nome. Ele está bem de vida e dá só 250 cruzeiros para a Vera. Ele só aparece quando eu saio nos jornais. Vem saber quanto eu ganhei" (JESUS, 1993b, p. 165).
} 
Como se vê, essa possibilidade de ação do grupo das mulheres brancas no interior da lógica do despejo comporta a manutenção dessa mesma lógica no interior dos limites estritos de seu arranjo social. Na sequência, há o grupo dos homens subalternos: negros, judeus, nortistas e ciganos. Todos são vítimas de uma ou mais formas de violência e encontram-se em situação social fragilizada, embora - conforme a lógica do despejo - sejam igualmente responsáveis por despejar esses atos de violência contra os demais grupos de status social inferior ou igual ao deles. Apenas isso explica formulações como estas:

14 de setembro de 1958. ... Hoje é o dia da pascoa de Moysés. O Deus dos judeus. Que libertou os judeus até hoje. O preto é perseguido porque a sua pele é da cor da noite. E o judeu porque é inteligente. Moysés quando via os judeus descalços e rotos orava pedindo a Deus para dar-lhe conforto e riquesas. É por isso que os judeus quase todos são ricos. Já nós os pretos não tivemos um profeta para orar por nós. (JESUS, 1993b, p. 107-8)

29 de junho de 1958. [...] Deu-se uma confusão tremenda. Os nortistas falavam e eu não entendia nada. Se no Norte deles for assim, o Norte deve ser horroroso. (JESUS, 1993b, p. 68)

23 de novembro de 1958. ... Preparei uns ferros para ir vender no deposito de ferro velho. Dei duas viagens. Ganhei 178 cruzeiros. Telefonei para as Folhas para mandar uns reporteres na favela para expulsar uns ciganos que estão acampados aqui. Eles jogam excrementos na rua. As pessoas que reside perto dos ciganos estão queixando que eles falam a noite toda. E não deixam ninguem dormir. Eles são violentos e os favelados tem medo deles. Mas eu já preveni que comigo a sopa é mais grossa.

Devido as mocinhas ficar nuas, os vagabundos ficam sentados perto do barracão, observandoas. O diabo é que se alguem agredi-las os ciganos revoltam. Mas a nudez delas excita. Parece que já estou vendo um bate-fundo de cigano com favelado.

Mil vezes os nossos vagabundos do que os ciganos. (JESUS, 1993b, p. 122-123)

Como se vê a partir dessas passagens, vigora aí a noção de que a violência sofrida por esses grupos subalternos - advinda em grande parte da predominância social dos brancos ${ }^{14}$ - é mutuamente despejada uns sobre os outros. $\mathrm{E}$, ainda que os negros apareçam de uma perspectiva mais positiva do que os demais subgrupos, isso se deve antes a uma identificação da própria narradora do que à sugestão de que eles adotassem práticas distintas dos outros. Em todo caso, o grupo dos homens subalternos é extremamente próximo - para bem ou para mal - daquele formado pelas mulheres subalternas: nessa relação surge a possibilidade de um sentimento tenro de amor $e$ de carinho, ${ }^{15}$ mas é a partir daí também que se dão as mais cotidianas manifestações de violência.

A violência masculina contra a mulher é tematizada frequentemente por Carolina - para quem mais vale a vida miserável de mulher solteira do que a vida dolorida de mulher casada (JESUS, 1993b, p. 119; p. 137; p. 148) - e, ainda que a perspectiva adotada nem sempre seja favorável à vítima da violência, a autora está consciente da posição ocupada pelas mulheres subalternas na lógica do despejo:

26 de julho de 1959. ... Era 19 horas quando o senhor Alexandre começou a brigar com a sua esposa. Dizia que ela havia deixado seu relogio cair no chão e quebrar-se. Foi alterando a voz e começou a espancá-la. Ela pedia socorro. Eu não imprecionei, porque já estou acostumada com os espetaculos que ele representa. A Dona Rosa correu para socorrer. Em um minuto, a noticia circulou que um homem estava matando a mulher. Ele deu-lhe com um ferro na cabeça. O sangue jorrava. Fiquei nervosa. O meu coração parecia a mola de um trem em movimento. Deu-me dor de cabeça. (JESUS, 1993b, p. 162)

O último grupo no interior dessa lógica do despejo é composto por crianças e animais. Vítimas da violência de todos os demais grupos, inclusive das mulheres subalternas, tanto as crianças quanto os animais são aqueles que mais frequentemente sofrem, embora sejam os menos capazes de infligir sofrimento aos outros. Embora a própria narradora participe da lógica do despejo em alguns momentos - como quando se volta contra os gibis lidos por seu filho, João José (JESUS, 1993, p. 112; p. 117) -, na maior parte do tempo ela se apieda das condições infantil e animal - sentindo inclusive certa empatia com elas. ${ }^{16}$ Aqui, porém, basta citar duas passagens e acredito explicitar de vez o funcionamento da lógica do despejo:

23 de junho de 1958. ... Passei no açougue para comprar meio quilo de carne para bife. Os preços eram 24 e 28. Fiquei nervosa com a diferença dos preços. O açougueiro explicou-me que o filé é mais caro. Pensei na desventura da vaca, a escrava do homem. Que passa a existencia no mato, se alimenta com vegetais, gosta de sal mas o homem não dá porque custa

\footnotetext{
${ }^{14}$ Em outra passagem, a narradora especifica o seguinte: "21 de agosto de 1958. ... Fiz café e mandei os filhos lavarse para ir na escola. Depois saí e fui catar papel. Passei no Frigorifico e a Vera foi pedir salsicha. Ganhei só 55 cruzeiros. Depois voltei e fiquei pensando na minha vida. O Brasil é predominado pelos brancos. Em muitas coisas eles precisam dos pretos e os pretos precisam deles. (...)" (JESUS, 1993b, p. 102)

${ }^{15}$ As manifestações afetivas de Carolina são escamoteadas no texto, mas algumas passagens onde elas se dão a ver seriam: JESUS, 1993b, p. 119; p. 137; p. 148.
} 
caro. Depois de morta é dividida. Tabelada e selecionada. E morre quando o homem quer. Em vida dá dinheiro ao homem. E morta enriquece o homem. Enfim, o mundo é como o branco quer. Eu não sou branca, não tenho nada com estas desorganizações. (JESUS, 1993b, p. 63)

1 de julho de 1958. [...] ... O baiano esposo de dona Zefa é meu vizinho e veio queixar-se que o José Carlos the aborrece. O que eu sei é que com tantos baianos na favela os favelados veteranos estão mudando-se. Eles querem ser superior pela força. Para ficar livre deles os favelados fazem um sacrificio e compram um terreno e zarpam-se. Eu disse-lhe:

- Teus filhos tambem aborrece-me. Abre as minhas gavetas e o que eles encontram carregam. - Eu não sabia disso.

E nem ia saber porque eu não faço reclamações de crianças. Porque eu gosto das crianças. ... Aqui reside uma nortista que é costureira. Eu gostava muito dela. Lhe favorecia no que eu podia. Um dia o meu filho José Carlos estava brincando perto da casa dela e ela jogou-lhe agua. No outro dia veio um caminhão jogar abacaxi podre aqui na favela e eu perguntei a ela porque havia jogado agua no meu filho.

- Eu joguei fria. Mas se ele me aborrecer outra vez eu quero jogar é agua quente com soda para ele não enchergar mais e não aborrecer mais ninguem.

A minha simpatia pela dona Chiquinha arrefeceu. (...) No outro dia a dona Chiquinha veio perguntar se eu queria brigar com ela que ela ia buscar a peixeira. Não the dei confiança. (JESUS, 1993b, p. 70)

\section{Des(p)ejo das palavras}

Nos diários de Carolina, contudo, a lógica do despejo não termina com a constatação de uma situação social inexorável contra a qual não seria possível se revoltar a fim de modificá-la. Ainda que os momentos de reversão da lógica do despejo sejam raros, a consciência que a narradora tem do poder transformador das palavras - seja por meio da escrita, seja por meio da voz-, em sua expressão dos desejos mais profundos de um sujeito, guia seu processo gradual de subjetivação e atuação direta sobre as estruturas sociais dessa lógica perversa. Ao retomar a escrita de seus diários, após quase três anos de interrupção, Carolina anota o seguinte:

2 de maio de 1958. Eu não sou indolente. Há tempos que eu pretendia fazer o meu diario. Mas eu pensava que não tinha valor e achei que era perder tempo.

... Eu fiz uma reforma em mim. Quero tratar as pessoas que eu conheço com mais atenção. Quero enviar um sorriso amável as crianças e aos operarios. (JESUS, 1993b, p. 25)

Carolina revela-se alguém que acredita no poder transformador das palavras - na capacidade de reverter a lógica do despejo por meio delas - e não se cansa de propalar a força da escrita (JESUS, 1993b, p. 19; p. 35; p. 43-44; p. 54). É certo que, de uma perspectiva pessoal, as palavras são as armas com que Carolina há de lutar por seu destino excêntrico, ${ }^{17}$ contudo, mesmo de uma perspectiva geral, as palavras são o meio para a transformação de toda a realidade. Tal é a possibilidade que ela sugere quando, em 28 de junho de 1958, depois de ter lido no jornal sobre a prisão de "Zuza", um político mau-caráter, afirma o seguinte: "Eu disse a Zuza que ele ia sair no jornal. Eu ouvi um senhor dizendo que o Zuza era malandro. Mas foi as pragas das mães que gastaram dinheiro e não ganharam nada que pegou igual o visgo" (JESUS, 1993b, p. 67). A mesma dimensão quase mágica da palavra manifesta-se também no incidente em que a maldade de uma mulher branca acaba se voltando contra ela própria:

8 de junho de 1958. [...] Uma tarde de terça-feira. A sogra de Dona Ida estava sentada e disse: - Podia dar uma enchente e arrazar a favela e matar estes pobres cacetes. Tem hora que eu revolto contra Deus por ter posto gente pobre no mundo, que só serve para amolar os outros. A Tina da Dona Mulata, quando soube que a sogra da Dona lda pedia a Deus para enviar uma enchente para matar os pobres favelados, disse:

- Quem há de morrer afogado há de ser ela!

Na enchente de 49 morreu o Pedro Cardoso, filho de Dona Ida. Quando eu soube que o Pedrinho havia morrido afogado pensei na decepção que teve sua avó que pedia agua, agua, bastante agua para matar os favelados e veio agua e matou-lhe o neto. É para ela compreender que Deus é sobrio. É o advogado dos humildes. Os pobres são criaturas de Deus. E o dinheiro é um metal criado e valorisado pelo homem. (...) Se Deus avisasse a Dona Ida que ela por não nos dar agua ia perder o seu filho para sempre, creio que ela estaria nos dando agua até hoje. O Pedro pagou em holocausto o orgulho de sua avó. E a maldade de sua mãe. É assim que Deus repreende. (JESUS, 1993b, p. 50)

\footnotetext{
${ }^{16}$ A título de exemplo, o que ela firma sobre a situação das crianças: JESUS, 1993b, p. 13; p. 70; p. 72. Sobre a situação dos animais (inclusive como padrão para se pensar a situação do subalterno): JESUS, 1993b, p. 55; p. 63; p. 104; p. 114; p. 115; p. 144; p. 163. A questão da animalidade é muito presente na obra de Carolina.

17 É o que se evidencia quando ela anota o seguinte no dia 2 de junho de 1958: “[...] (...) O senhor Manuel apareceu dizendo que quer casar-se comigo. Mas eu não quero porque já estou na maturidade. E depois, um homem não há de gostar de uma mulher que não pode passar sem ler. E que levanta para escrever. E que deita com lapis e papel debaixo do travesseiro. Por isso é que eu prefiro viver só para o meu ideal" (JESUS, 1993b, p. 44).
} 
Em ambos os casos, trata-se da manifestação de uma dimensão quase mágica - ou divina - da palavra. E não poderia ser muito diferente, uma vez que é por meio dela que a lógica do despejo se vê alterada. É por isso que mesmo num emprego mais mundano de seu poder, a palavra continua guardando seu aspecto fantástico e transformador: tal é o que se mostra quando Carolina consegue se voltar contra a violência que seria praticada contra ela por um homem:

7 de julho de 1958. ... Fui na dona Juana, ela deu-me pães. Passei na fábrica para ver se tinha tomates. Havia muitas lenhas. Eu ia pegar uns pedaços quando ouvi um preto dizer para eu não mecher nas lenhas que ele ia bater-me. Eu disse para bater que eu não tenho medo. Ele estava pondo as lenhas dentro do caminhão. Olhou-me com desprezo e disse:

- Maloqueira!

- Por eu ser de maloca é que você não deve mecher comigo. Eu estou habituada a tudo. A roubar, brigar e beber. Eu passo 15 dias em casa e quinze dias na prisão. Já fui sentenciada em Santos.

Ele fez menção de agredir-me e eu disse-lhe:

- Eu sou da favela do Canindé. Sei cortar de gilete e navalha e estou aprendendo a manejar a peixeira. Um nordestino está me dando aulas. Se vai me bater pode vir.

Comecei a apalpar os bolsos.

- Onde será que está minha navalha? Hoje o senhor fica só com uma orelha. Quando eu bebo umas pingas fico meio louca. Na favela é assim, tudo que aparece por lá nós batemos e roubamos o dinheiro e tudo que tiver no bolso.

O preto ficou quieto. Eu vim embora. Quando alguem nos insulta é só falar que é da favela e pronto. Nos deixa em paz. Percebi que nós da favela somos temido. Eu desafiei o preto porque eu sabia que ele não ia vir. Eu não gosto de briga. (JESUS, 1993b, p. 73)

A possibilidade de que os oprimidos pela lógica do despejo se deem conta de suas misérias e se revoltem contra todo o sistema que é responsável por acarretá-las passa inevitavelmente por esse poder da palavra. Carolina sabe disso (JESUS, 1993b, p. 36; p. 30; p. 114) e seus companheiros de luta também o reconhecem. ${ }^{18}$ Não é à toa, portanto, que inúmeros atos de violência sejam cometidos justamente contra o poder da palavra possuído por Carolina (JESUS, 1993b, p. 19; p. 24; p. 69), e uma de suas manifestações mais abjetas seja aquela que se vale da própria palavra escrita para atingi-la em sua subjetividade feminina atuante:

30 de agosto de 1958. [...] Fui no senhor Eduardo comprar querosene, oleo, e tinta para escrever. Quando eu pedi o tinteiro, um homem que estava perto perguntou-me se eu sabia ler. Disse-lhe que sim. Ele pegou o lapis e escreveu:

A senhora é casada? Se não for quer dormir comigo?

Eu li e entreguei-Ihe, sem dizer nada. (JESUS, 1993b, p. 106)

Carolina resiste às várias tentativas de objetificação sexual (JESUS, 1993b, p. 74; p. 166). Dedica-se com ainda mais afinco àquilo que seria possível compreender como o des(p)ejo das palavras - esse avesso da lógica do despejo - e sustenta uma palavra altiva, fazendo-a ressoar em sua realidade cotidiana e em seu diário, com o poder transformador que lhe é caro. Esse deslize do significante "despejo" como aquilo que se contrapõe e resiste à realização do "desejo" é algo tão evidente para a narradora de Quarto de despejo que a primeira anotação de sua primeira obra publicada é a seguinte:

15 de julho de 1955. Aniversário de minha filha Vera Eunice. Eu pretendia comprar um par de sapatos para ela. Mas o custo dos gêneros alimenticios nos impede a realização dos nossos desejos. Atualmente somos escravos do custo de vida. Eu achei um par de sapatos no lixo, lavei e remendei para ela calçar. (JESUS, 1993b, p. 9, grifo meu)

A lógica do despejo impossibilita a realização plena do desejo. Contudo, assim como a impossibilidade de presentear plenamente a filha no dia de seu aniversário converte-se na ocasião para pelo menos oferecer-lhe algo que supra sua necessidade mais básica de um calçado, da mesma forma, seu aniversário será convertido na oportunidade para dar início a um relato de uma "Verdadeira Boa Vitória" (expressão que traduzo nome de Vera Eunice, a partir do latim e do grego). Tudo conforme a lógica de um des(p)ejo das palavras.

Essa mesma concepção guia suas considerações sobre o preconceito racial - pautadas por uma argumentação religiosa-, quando afirma:

20 de setembro de 1958. [...] Então começamos a falar sobre o preconceito. Ela disse-me que nos Estados Unidos eles não querem negros nas escolas.

Fico pensando: os norte-americanos são considerados os mais civilisados do mundo e ainda não convenceram que preterir o preto é o mesmo que preterir o sol. $\mathrm{O}$ homem não pode lutar

\footnotetext{
${ }^{18}$ Carolina demonstra sua empatia pela luta operária em certas passagens, mas esse reconhecimento do poder transformador de sua própria palavra se revela na anotação de 16 de agosto de 1958: "Quando eu passava na Avenida Tiradentes, uns operarios que saíam da fabrica disse-me: - Carolina, já que você gosta de escrever, instiga o povo para adotar outro regime" (JESUS, 1993b, p. 100).
} 
com os produtos da Natureza. Deus criou todas as raças na mesma epoca. Se criasse os negros depois dos brancos, aí os brancos podia revoltar-se. (JESUS, 1993b, p. 108)

Ainda que o argumento em si seja defendido de uma maneira pouco convencional, Carolina mostra-se atenta para a necessidade de políticas públicas afirmativas a fim de que os marginalizados tenham acesso à grande arma que é representada pela palavra e pela educação. ${ }^{19}$ Além disso, um jogo análogo ao que ela estabelece entre "preto" e "preterir" já havia sido trabalhado numa passagem anterior, na qual o verbo "pretere" era aproximado do verbo "prefere", e em ambos os casos constata-se o des(p)ejo das palavras (JESUS, 1993b, p. 44). É também o que subjaz à possibilidade de manter um pouco de bom-humor, mesmo diante do quadro da mais terrível miséria (JESUS, 1993b, p. 58; p. 73; p. 89; p. 95-96; p. 99; p. 106; p. 132; p. 146), e de permitir que certos devaneios a transportem dessa triste realidade para uma atmosfera fantástica e divina de bem-estar. A própria narradora deixa claro que o desejo das palavras é o que the oferece a possibilidade de sobrepujar a lógica do despejo:

12 de junho de 1958. Eu deixei o leito as 3 da manhã porque quando a gente perde o sono começa a pensar nas miserias que nos rodeia. (...) Deixei o leito para escrever. Enquanto escrevo vou pensando que resido num castelo cor de ouro que reluz na luz do sol. Que as janelas são de prata e as luzes de brilhantes. Que a minha vista circula no jardim e eu contemplo as flores de todas as qualidades. (...) É preciso criar este ambiente de fantasia, para esquecer que estou na favela. (JESUS, 1993b, p. 52)

O mesmo se dá num sonho narrado por ela em 2 de setembro de 1958, no qual as próprias estrelas conversam com Carolina e organizam um espetáculo para homenageá-la (JESUS, 1993b, p. 107). Trata-se, mais uma vez, do des(p)ejo das palavras.

Em todo caso, a própria narradora - em várias passagens de seu texto, mesmo da forma mutilada com que ele veio a ser publicado - mostra-se consciente dos inúmeros desdobramentos aqui sugeridos. Subjacente às mazelas sociais retratadas por sua parataxe da miséria, há o funcionamento de uma perversa lógica do despejo - despejo da violência, tanto física quanto moral - e a única possibilidade de reverter essa lógica passa inevitavelmente pelo des(p)ejo das palavras. Seja numa modalidade revolucionária - como a simpatia de Carolina pela causa operária o indica -, seja numa modalidade apaziguadora - como o elogio ao poder transformador da educação o sugere -, a narradora de Quarto de despejo defende a necessidade de um diálogo aberto entre todos os setores da sociedade, por meio de uma palavra efetivamente plena.

\section{Considerações finais}

Nossa situação política hoje - no início de 2018 -, mais de cinquenta anos após a escrita dos primeiros diários de Carolina Maria de Jesus, carece que seu apelo tenha uma nova ressonância. A lógica do despejo ganha traços cada vez mais cruéis com o avanço do neoliberalismo, o recrudescimento dos discursos autoritários e a expansão do poder de polícia. É imprescindível que, alertados pela parataxe da miséria empregada por Carolina para retratar um estágio anterior dessa mesma realidade social, resistamos à lógica do despejo - cujo mecanismo implica no silenciamento de tantas vozes capazes de fazer coro aos ecos vindos de seu Quarto de despejo. É imprescindível que nos engajemos politicamente por meio de um sempre renovado des(p)ejo das palavras, a fim de que nunca esqueçamos do orgulho de Carolina quando afirma o seguinte: "Se é que existe reincarnações, eu quero voltar sempre preta" (JESUS, 1993b, p. 58).

\section{Referências}

ADORNO, Theodor. Parataxis. Zurspäten Lyrik Hölderlins. In: Noten zur Literatur III. Gesammelte Schriften. Frankfurt am Main: Suhrkamp, 1997. p. 447-491.

COMPAGNON, Antoine. O demônio da teoria: literatura e senso comum. Tradução de Cleonice Paes Barreto Mourão, Consuelo Fortes Santiago. 2. ed. Belo Horizonte: Editora UFMG, 2010.

DALCASTAGNÈ, Regina. "A auto-representação de grupos marginalizados: tensões e estratégias na narrativa contemporânea." Letras de Hoje, Porto Alegre, v. 42, n. 4, p. 18-31, dez. 2007.

DANTAS, Audálio. "A atualidade do mundo de Carolina." In: JESUS, Carolina Maria de. Quarto de despejo: diário de uma favelada. São Paulo: Editora Ática, 1993. p. 3-5.

DAVIS, Angela. Mulheres, raça e classe. Trad. Heci Regina Candiani. 1. ed. São Paulo: Boitempo, 2016.

\footnotetext{
19 A mesma necessidade era sentida e defendida, segundo Angela Davis (2016, p. 107-116), entre os negros escravizados nos Estados Unidos desde o séc. XVIII, numa luta que continua até hoje.
} 
FERNANDEZ, Raffaella Andréa. Processo criativo nos manuscritos do espólio literário de Carolina Maria de Jesus. Tese (Doutorado em Teoria e História Literária) - Instituto de Estudos da Linguagem, Universidade Estadual de Campinas, Campinas, SP, Brasil, 2015.

FORTUNA, Maria. "Livro de ex-catadora provoca 'racha' na Academia Carioca de Letras." O Globo [online]. Rio de Janeiro, 19/04/2017. Disponível em: https://blogs.oglobo.globo.com/gente-boa/ post/livro-de-ex-catadora-provoca-racha-na-academia-carioca-de-letras.html. Acesso em: 05/08/ 2018.

GUIMARÃES, Cleo; FORTUNA, Maria. "'Racha' entre intelectuais sobre obra de Carolina de Jesus: clima cada vez mais tenso." O Globo [online]. Rio de Janeiro, 22/04/201 7. Disponível em: https:// blogs.oglobo.globo.com/gente-boa/post/racha-entre-intelectuais-sobre-obra-de-carolina-dejesus-clima-cada-vez-mais-tenso.html. Acesso em: 05/08/2018.

JESUS, Carolina Maria de. "A literatura e a fome." In: Quarto de despejo: diário de uma favelada. São Paulo: Editora Ática, 1993a. p. 169-173.

JESUS, Carolina Maria de. Quarto de despejo: diário de uma favelada. São Paulo: Editora Ática, 1993b.

KRISTEVA, Julia. "O texto e sua ciência." In: Introdução à semanálise. Trad. de Lucia Helena França Ferraz. São Paulo: Signos, 1974.

LAJOLO, Marisa. "Carolina Maria de Jesus." In: DUARTE, Eduardo de Assis (Org.). Literatura e afrodescendência no Brasil: Antologia Crítica. Volume 1: Precursores. Belo Horizonte: Editora UFMG, 2011. p. 439-458.

LUCINDA, Elisa. “Carolina de Jesus é literatura sim!" Publishnews [online]. São Paulo, 24/04/2017. Disponível em: http://www.publishnews.com.br/materias/2017/04/24/carolina-de-jesus-e-literaturasim. Acesso em: 05/08/2018.

MUZART, Zahidé Lupinacci. "A questão do cânone." Anuário de Literatura, Florianópolis, v. 3, p. 8594, 1995.

PEREGRINO, Miriane. "A Favela dá Escritor?" O Cidadão do Bairro Maré [online]. Rio de Janeiro, 23/ 04/2017. Disponível em: http://jornalocidadao.net/a-favela-da-escritor/. Acesso em: 05/08/2018.

PERPÉTUA, Elzira Divina. A vida escrita de Carolina Maria de Jesus. Belo Horizonte: Nandyala, 2014.

RIBEIRO, Djamila. O que é lugar de fala? Belo Horizonte: Letramento; Justificando, 2017.

SILVEIRA, Sara Juliana Pozzer. "Adorno e a poesia tardia de Hölderlin." Literatura e autoritarismo, Dossiê Theodor Adorno e o Estudo da poesia, n. 12, 2012, p. 78-98.

SOUSA, Germana Henriques Pereira. Carolina Maria de Jesus: O estranho diário da escritora vira lata. Vinhedo: Editora Horizonte, 2012.

SPIVAK, Gayatri Chakravorty. Pode o subalterno falar? Trad. Sandra Regina Goulart Almeida, Marcos Pereira Feitosa, André Pereira Feitosa. Belo Horizonte: Editora UFMG, 2014.

Rafael Guimarães Tavares da Silva (gts.rafa@hotmail.com) é estudante de Língua e Literatura Clássicas (Grego Antigo), doutorando no POS-LIT da UFMG, com interesses que vão da Filosofia e da História (Antigas e Contemporâneas) à Teoria da Literatura, além de teoria e prática da Tradução e da Educação. Trabalha diversos temas relacionados à literatura e ao teatro, em abordagens marcadas principalmente pelo viés da desconstrução e do pós-estruturalismo. Elaborou uma monografia sobre Uma poética de Platão, uma dissertação chamada Arqueologias do drama: uma arqueologia dramática e atualmente desenvolve sua tese Os Estudos Clássicos na Universidade Contemporânea. Participa da organização do Seminário de Estudos Clássicos e Medievais, ligado ao NEAM, e atua, desde 2016, no Apoio Pedagógico da FALE-UFMG.

\section{COMO CITAR ESSE ARTIGO DE ACORDO COM AS NORMAS DA REVISTA}

SILVA, Rafael Guimarães Tavares da. "Des(p)ejo das palavras: relendo os primeiros diários de Carolina Maria de Jesus". Revista Estudos Feministas, Florianópolis, v. 27, n. 2, e54825, 2019. 
DES(P)EJO DAS PALAVRAS: RELENDO OS PRIMEIROS DIÁRIOS DE CAROLINA MARIA DE JESUS

CONTRIBUIÇÃO DE AUTORIA

Não se aplica

FINANCIAMENTO

Bolsa de pós-graduação (doutorado) do CNPq

CONSENTIMENTO DE USO DE IMAGEM

Não se aplica

APROVAÇÃO DE COMITÊ DE ÉTICA EM PESQUISA

Não se aplica

CONFLITO DE INTERESSES

Não se aplica

LICENÇA DE USO

Este artigo está licenciado sob a Licença Creative Commons CC-BY Internacional. Com essa licença você pode compartilhar, adaptar, criar para qualquer fim, desde que atribua a autoria da obra.

HISTÓRICO

Recebido em 13/01/2018

Reapresentado em 06/08/2018

Aprovado em 09/08/2018

Revista Estudos Feministas, Florianópolis, 27(2): e54825

DOI: 10.1590/1806-9584-2019v27n254825

13 